\title{
O PAPEL SOCIAL FEMININO NO CONTO “A FUGA”, DE CLARICE LISPECTOR
}

\section{THE FEMININE SOCIAL ROLE IN THE SHORT STORY “A FUGA”, BY CLARICE LISPECTOR}

\author{
Ana Paula Franco Nobile Brandileone* \\ UENP
}

\section{Lorena Salviano Alves** G-UENP}

Resumo: Este artigo teve por objetivo analisar o conto “A fuga”, de Clarice Lispector, publicado no ano de 1940, a fim de discutir aspectos ligados ao papel feminino, figurado na protagonista Elvira. Buscou-se situar a produção literária da autora no contexto da década de 1940, quando ainda predominavam narrativas de cunho regionalista. No que tange aos resultados obtidos com a presente análise, que se deu sob à luz de estudos de Brasil (1969), Candido (1970, 1987a, 1987b), Süssekind (1984), Nunes (1989), Santiago (1999), Bourdieu (2012), Bosi (2015), Zolin (2015), entre outros, foi possível constatar que a autora, além de apresentar um modelo narrativo e estético dissonante à ficção de 1940, fraturando o compromisso de retratar a realidade brasileira, também desnudou a realidade social feminina, promovendo uma crítica aos valores patriarcais e aos padrões dominantes de gênero.

Palavras-chave: Clarice Lispector. “A fuga”. Novo modelo narrativo e estético. Papel social feminino.

\begin{abstract}
This article aimed to analyze the short story "A fuga", by Clarice Lispector, published in 1940, in order to discuss aspects related to the feminine role, represented by the protagonist Elvira. It was sought to situate the literary production of the author in the context of the 1940s, period when regionalist narratives prevailed, figuring aspects of the national reality. Regarding the results obtained with this analysis, based on studies by Brasil (1969), Candido (1970, 1987a, 1987b), Süssekind (1984), Nunes (1989), Santiago (1999), Bourdieu (2012), Bosi (2015), Zolin (2015), among others, it was possible to verify that the author, besides presenting a narrative and esthetic model dissonant of the fiction of 1940, fracturing the commitment to present the Brazilian reality, also revealed the feminine social reality, promoting a critique of patriarchal values and dominant gender patterns.
\end{abstract}

Keywords: Clarice Lispector. “A fuga”. New narrative and esthetic model. Feminine social role.

\footnotetext{
${ }^{*}$ Professora Associada do curso de Letras e docente do Programa de Mestrado Profissional em Letras (PROFLETRAS) da Universidade Estadual do Norte do Paraná (UENP). ORCID: https://orcid.org/0000-0001-5446-3957. E-mail: <apnobile@uenp.edu.br>.

** Graduanda do curso de Letras da Universidade Estadual do Norte do Paraná (UENP). ORCID: https://orcid.org/0000-0003-23751504. E-mail: <lorenasalviano@outlook.com>.
} 


\section{CLARICE LISPECTOR NO CENÁRIO LITERÁRIO BRASILEIRO DO SÉCULO XX}

No ano de 1943, Clarice Lispector foi projetada no cenário literário moderno brasileiro com o romance intitulado Perto do coração selvagem. Apesar de, atualmente, suas obras serem apreciadas positivamente, na década de 1940 seu romance de estreia foi recepcionado com resistência por parte dos críticos da época, como é o caso de Álvaro Lins, em 1944, em artigo

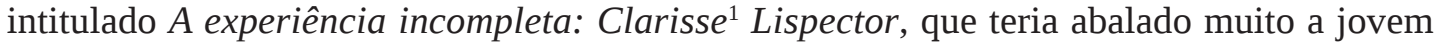
estreante. Apesar de reconhecer a originalidade do romance, Lins entende que a autora faz uso exacerbado do lirismo, o que acaba por desnudar uma personalidade particular, esta, segundo o crítico, característica própria da escrita das mulheres: “O que se deve fixar, antes de tudo, em Perto do coração selvagem, será exatamente, aquela personalidade da sua autora, a sua estranha natureza humana” (LINS, 1944, p. 189). Já o título do artigo, refere-se às ponderações finais do crítico, que reverberam a impressão de que o romance não estava realizado, sua estrutura como obra de ficção estava incompleta/inacabada.

Na contramão de Lins (1944), Milliet afirmou com otimismo: "Raramente o crítico tem a alegria da descoberta" (MILLIET apud SANTIAGO, 1999, p. 13). Antes de Lins e Milliet, Candido (1970), no ano da publicação da obra, mostrou-se surpreendido com a estreante autora, que teria dado, à nossa literatura moderna, um romance de tom "mais ou menos raro". Não obstante o autor considerar a autora ainda uma principiante, reconheceu na obra de Clarice Lispector a ousadia e a raridade, comparada a outros escritores da época: “[...] dentro da nossa literatura, é performance da melhor qualidade” (CANDIDO, 1970, p. 128, grifo do autor). Mais tardiamente, Santiago (1999) vislumbra nela a novidade, por inaugurar um "novo curso" na literatura no Brasil.

Inserindo a estreia de Clarice Lispector no contexto da história da literatura brasileira do século XX, Santiago (1999) afirma que a escritora rompeu com pressupostos estéticos e ideológicos alicerçados no instinto e/ou na consciência de nacionalidade, fraturando os moldes da trama novelesca oitocentista, a qual trazia à tona, de forma direta ou indireta, acontecimentos da vida nacional. Isso quer dizer que a ficção estava, até então, “[...] a serviço de acontecimentos, seja atrelada a eles, para confirmá-los e dar-lhes peso institucional, seja em descrença deles, para negá-los e, dessa maneira, dar-lhes peso pelo avesso crítico” (SANTIAGO, 1999, p. 13). Entre alguns desses acontecimentos da formação colonial e do desenvolvimento nacional que concorrem para a afluência das tramas novelescas, estão a descoberta do Brasil, a colonização europeia, os acontecimentos ligados à escravidão, à independência e à república no Brasil, bem como à modernização da nação. Nesse contexto, a "boa” literatura brasileira, antes de Clarice, ligava-se a esses aspectos da vida brasileira, o que inclui a caracterização e o desenvolvimento dos personagens, espaço narrativo e trama novelesca naturalista.

Nessa perspectiva, Clarice não apenas dá as costas para a auréola interpretativa do acontecimento, como também à era do romance brasileiro das décadas de 1930 e 1940, que estava fundada nas obras regionalistas e de teor social, inaugurando "[...] uma tradição sem fortuna, desfortunada, feminina e, por ricochete, subalterna” (SANTIAGO, 1999, p. 15). Em linhas gerais, o denominado romance social está assentado no enfoque sobre a vida dos humildes,

${ }^{1}$ Como grafado no artigo de Álvaro Lins. 
na obsessão fotográfica e documental, daí a descrição minuciosa de ambientes e das sugestões da natureza, e nos personagens, na sua grande maioria, sem densidade psicológica. E, assim como a ficção oitocentista, não pressupõe obras e autores que se isentem de retratar o "instinto de nacionalidade”, ou, como quer Süssekind (1984, p. 31), que “[...] não deixem traços claros de brasilidade nos seus textos”. Diferentemente daquela, a ficção brasileira de 1930 incorpora o espírito crítico da época, absorvida pela noção de "país subdesenvolvido”. Dessa perspectiva desalentada da realidade brasileira é que nasce a denúncia social e o caráter engajado dos textos literários, tão cobrado à época. A euforia e a esperança, que se alicerçavam na ideia de um país que atribuía a si mesmo grandes possibilidades de progresso no futuro, deram lugar ao pessimismo; da “noção de país novo” para a noção de "país subdesenvolvido”:

O precedente gigantismo de base paisagística aparece então na sua essência verdadeira - como construção ideológica transformada em ilusão compensadora. Daí a disposição de combate que se alastra pelo continente, tornando a ideia de subdesenvolvimento uma força propulsora, que dá novo cunho ao tradicional empenho político dos nossos intelectuais. (CANDIDO, 1987a, p. 142).

É, então, nesse contexto estético e político, dada a militância dos romances sociais, que o romance Perto do Coração Selvagem foi publicado; na contramão do que até então era a tônica da ficção brasileira. Não por acaso, Santiago (1999) busca evidenciar a novidade da ficção de Clarice nas letras nacionais que, em vez de tematizar as classes oprimidas e desamparadas da sociedade e, portanto, o caráter coletivo da sociedade brasileira, centrou-se no indivíduo; em vez do engajamento social, firmou-se sobre o mundo construído na introspecção, num claro apego a ideias e rumos universais, em detrimento do realismo objetivo.

Ecoando como uma voz dissonante na ficção brasileira da época por violar o compromisso da literatura brasileira com a identidade nacional, como aponta Santiago (1999, p. 14), é que a produção literária de Lispector foi considerada sentimental, como a de “[...] querer demonstrar que o compromisso do texto ficcional não era com a interpretação do acontecimento propriamente dito, mas com certa emoção privada que estava sendo desnudada pela escrita e, em seguida, entregue em letra impressa ao público”. É o caso de Candido (1970, p. 128), quando assevera: "Clarice Lispector aceita a provocação das coisas à sua sensibilidade e procura criar um mundo partindo das suas próprias emoções, da sua própria capacidade de interpretação”.

Dada a incompreensão dos traços característicos da sua ficção, Clarice obteve reconhecimento da crítica e do público apenas anos mais tarde. Para Candido (1987b), o “toque novo” do seu romance de estreia estava assentado na prioridade dada à linguagem literária e que colocava em segundo plano o tema. Desse modo, a elaboração do texto torna-se aspecto decisivo para que a ficção atinja o seu máximo efeito. Nesse sentido, não se trata mais de ver o texto como algo que se esgota em determinados aspectos do mundo e do ser, uma vez que só existem e atuam na medida em que é discurso literário. Concepção de literatura que exigiu dos críticos uma mudança de ponto de vista: de um lado, considerar que a força da ficção também pode residir na criação “mundos imaginários”; e, de outro, reconsiderar a atitude disjuntiva de catalogar determinada obra como de direita ou de esquerda, psicológico ou social. Sob esse viés, Candido (1987b, p. 210) afirma: "Ela [Clarice] é provavelmente a origem das tendências desestruturastes, que dissolvem o enredo na descrição e praticam esta com gosto pelos contornos fugidios”. 
Também para Bosi (2015), a narrativa de Clarice Lispector rompe com o enredo factual ao se apropriar de metáforas insólitas e evidenciar o fluxo de consciência, colocando em destaque o universo íntimo de seus personagens; subjetividade que transcende o nível psicológico:

Há na gênese dos seus contos e romances tal exacerbação do momento interior que, a certa altura do seu itinerário, a própria subjetividade entra em crise. O espírito, perdido no labirinto da memória e da autoanálise, reclama um novo equilíbrio. Que se fará pela recuperação do objeto. Não mais na esfera convencional de algo-que-existe-para-o-eu (nível psicológico), mas na esfera da sua própria e irredutível realidade. O sujeito só "se salva” aceitando o objeto como tal; como a alma que, para todas as religiões, deve reconhecer a existência de um Ser que a transcende para beber nas fontes da sua própria existência. Trata-se de um salto do psicológico para o metafísico, salto plenamente amadurecido na consciência da narradora [...]. (BOSI, 2015, p. 452, grifo do autor).

Nesse contexto, é possível afirmar que, desde o seu surgimento nas letras brasileiras, os textos de Clarice buscam, por meio da linguagem, desnudar e revelar o que há de mais recôndito, daí centrarem-se na existência do indivíduo e na sua densa introspecção. Em seu famoso romance Água viva, a autora registra: “Quero como poder pegar com a mão a palavra [...]. Estou lidando com a matéria-prima. Estou atrás do que fica atrás do pensamento” (LISPECTOR, 1998a, p. 12-13).

Diante do exposto, pode-se dizer que, em meio às obras da segunda geração modernista, marcadas pela ficção regionalista de cunho social, fica explícito o rompimento causado pelo romance de estreia clariceano, conforme se destacou anteriormente, e que, apesar de ter sido recepcionada com resistência por parte dos críticos da época, anos mais tarde a autora se consagraria e conquistaria espaço próprio na literatura brasileira. Entretanto, para além da relevância de discutir a "novidade” trazida pela narrativa de Clarice em meio à produção literária nacional da década de 1940, este artigo teve por objetivo analisar o conto “A fuga”, produzido antes mesmo da publicação de Perto do coração selvagem - que levou a autora a ganhar visibilidade no cenário nacional -, a fim de explorar o papel social assumido pela protagonista, Elvira, que, vivendo em um casamento infeliz, resolve abandonar o lar. Ao centrar-se, portanto, em Elvira, na tentativa de desnudar sua subjetividade e revelar seus dilemas, o conto rompe com o compromisso de retratar a realidade do país, expondo ao leitor a realidade social feminina.

\section{APRISIONAMENTO VERSUS LIBERDADE: ANÁLISE DO CONTO “A FUGA"}

Publicado postumamente na coletânea A bela e a fera (LISPECTOR, 1999a), em 1979, o conto "A fuga” e outros sete englobam um conjunto de textos que foram escritos nas décadas de 1940 e 1970 por Clarice Lispector. Apesar da publicação tardia, “A fuga” data do ano de 1940; assim, o conto antecede a estreia da autora nas letras nacionais, com Perto do coração selvagem, em 1943. Publicado recentemente na coletânea Todos os contos (2016c), “A fuga” se insere na seção "Primeiras histórias”, que apresenta os seus primeiros escritos literários, que datam da fase da sua juventude, no início da década de 1940. Nesse período, Clarice ainda não era casada e atuava como jornalista e estudante de Direito, no Rio de Janeiro. 
Não é novidade que a produção contística e romanesca da autora coloca, na maioria das vezes, a figura feminina e seu cotidiano como centro da trama. Em "Primeiras histórias", por exemplo, dos dez contos que compõem a coletânea, oito são protagonizados por personagens femininas e revelam seus dilemas e experiências. Como prenunciado no título, o conto selecionado, intitulado “A fuga”, apresenta ao leitor a história de Elvira, uma mulher casada, que caminha pelas ruas do Rio de Janeiro em um dia chuvoso, após abandonar o lar. O motivo da fuga da protagonista é o sentimento de aprisionamento causado pelo casamento, que se acentua pela monotonia do seu dia a dia: “Abre a boca e sente o ar fresco inundá-la. Por que esperou tanto tempo por essa renovação? Só hoje, depois de doze séculos” (LISPECTOR, 2016a, p. 90-91). É, então, em um dia abafado e de calor sufocante, que Elvira, aliviada, toma a iniciativa de partir: "Um vento fresco circulava pela casa, aliviava o seu rosto quente. Ficou mais calma, então. Vestiu-se, juntou todo o dinheiro que havia em casa e foi embora” (LISPECTOR, 2016a, p. 91).

O desejo de renovação, o que inclui deixar de ser “mulher casada” para ser “apenas uma mulher”, é desencadeado pela epifania que, segundo Rosenbaum (2002), refere-se a uma repentina iluminação e/ou compreensão advinda das situações e dos gestos mais insignificantes do cotidiano; momento expresso no excerto a seguir:

Fazia calor e ela sufocava. Abriu todas as janelas e as portas. Mas não: o ar ali estava imóvel, sério, pesado. Nenhuma viração e o céu baixo, as nuvens escuras, densas. Como foi que aquilo aconteceu? A princípio apenas o mal-estar e o calor. Depois qualquer coisa dentro dela começou a crescer. De repente, em movimentos pesados, minuciosos, puxou a roupa do corpo, estraçalhou-a, rasgou-a em longas tiras. O ar fechava-se em torno dela, apertava-a. Então um forte estrondo abalou a casa. Quase ao mesmo tempo, caíam grossos pingos d’água, mornos e espaçados.

Ficou imóvel no meio do quarto, ofegante. A chuva aumentava. Ouvia seu tamborilar no zinco do quintal e o grito da criada recolhendo a roupa. Agora era como um dilúvio. Um vento fresco circulava pela casa, alisava seu rosto quente. Ficou mais calma, então. Vestiu-se, juntou todo o dinheiro que havia em casa e foi embora. (LISPECTOR, 2016a, p. 91).

No que tange à epifania, a chuva se revela um elemento de grande carga simbólica. No romance Uma aprendizagem ou o livro dos prazeres (LISPECTOR, 1998c), a chuva representa a transitoriedade e as transformações da protagonista Lóri; já no conto “A fuga”, atua como forma de expressão do estado de espírito de Elvira, como na crônica "Alegria mansa”, da coletânea A descoberta do mundo: "Vou então à janela, está chovendo muito. [...]. Estamos ocupadas ambas em fluir” (LISPECTOR, 1999b, p. 99). Por isso, os acontecimentos nas narrativas clariceanas adquirem importância secundária, como é o caso do conto em análise, já que a chuva é imagem criada pela autora para figurar os conflitos íntimos da protagonista e sua crise interior. Desse modo, é possível observar que a chuva, no momento epifânico, traz à tona o mundo subjetivo da personagem, corroborando o que é dito por Brasil (1969), que afirma que o episódio externo passa a adquirir uma importância secundária em relação à ação interna.

O excerto anterior de “A fuga” também configura o que Nunes (1989) denomina de tensão conflitiva, comumente encontrado nos escritos de Clarice. Esse conceito está relacionado a um episódio que se qualifica como núcleo da trama, vinculado diretamente à crise da personagem e à sua própria interioridade: “[...] o episódio único que serve de núcleo à narrativa 
é um momento de tensão conflitiva [...] tal momento de crise interior aparece diversamente condicionado e qualificado em função do desenvolvimento que a história recebe" (NUNES, 1989, p. 84, grifo do autor). No conto, o ato de libertar-se rasgando as vestes e, em seguida, experimentar o frescor trazido pela chuva que caia violentamente, relacionam-se diretamente aos dilemas vivenciados por Elvira que, naquele momento, inicia o processo de exercer as suas vontades, depois de 12 anos casada.

Ao mergulhar na vivência interior da personagem, o narrador deixa entrever uma mulher subjugada ao marido e "aprisionada” ao espaço doméstico, o que gera, ao longo da narrativa, um jogo de oposições representado pela dualidade de ideias relacionadas a duas palavras-chave: aprisionamento versus liberdade. Ainda que Elvira não realize trabalhos domésticos, sua rotina se institui no espaço da casa; representação comumente associada às personagens femininas nas obras literárias, incluindo os romances brasileiros contemporâneos (DALCASTAGNÈ, 2005; ZOLIN, 2015). Isso também se deve ao fato de o conto espelhar os valores vinculados à sociedade patriarcal que, desde a antiguidade, tem a ver com a noção de patriarcado que, por sua vez, remonta à autoridade do pater familias - expressão latina que se refere ao "pai de família" - e que aponta o homem como sujeito mais elevado no estatuto familiar. Cabe ressaltar que o patriarcado não significa, entretanto, apenas o poder do “pai” dentro das relações familiares, já que é uma organização social estruturada, centralizada na figura masculina e em sua supremacia (NOGUEIRA, 2016). Diante dessa hegemonia masculina, as mulheres acabam ocupando uma posição de subalternidade dentro dessa hierarquia social e, desse modo, destinadas a procriar e a viver no ambiente doméstico, enquanto os homens podem ocupar cargos e posições de prestígio, sendo, inclusive, considerados superiores intelectualmente.

Nesse contexto, a associação entre a figura da mulher, o lar e a família tornam-se símbolo não apenas da esfera íntima da mulher, mas também espaço de pertencimento da personagem feminina. Situação antagônica dos personagens masculinos, cuja circulação é variada e, portanto, vai além dos muros da casa. O mesmo se dá em relação às ocupações desempenhadas pelas mulheres, cujas funções estão relacionadas ao âmbito do lar, tarefas tradicionalmente tidas como femininas; o que revela uma espécie de obediência velada aos padrões dominantes. No caso de Elvira, ela passa os seus dias cuidando da filha, Rosinha, do compromisso de acordar o marido "às sete horas em ponto" e lendo livros; esta a atividade de "[...] todas as tardes dos dias de todos os anos” (LISPECTOR, 2016a, p. 91). É válido assinalar que ainda que a personagem seja uma construção fictícia, sugere ao leitor o funcionamento das relações sociais e de gênero. Para Bourdieu (2012), em A dominação masculina, a ordem social funciona como uma máquina simbólica que determina a divisão de tarefas, de espaços e de papéis sociais:

A ordem social funciona como uma imensa máquina simbólica que tende a ratificar a dominação masculina sobre a qual se alicerça: é a divisão social do trabalho, distribuição bastante estrita das atividades atribuídas a cada um dos dois sexos, de seu local, seu momento, seus instrumentos; é a estrutura do espaço, opondo o lugar de assembléia ou de mercado, reservados aos homens, e a casa, reservada às mulheres [...]. (BOURDIEU, 2012, p. 18).

No conto, Elvira desempenha papéis sociais de esposa, mãe e mulher do lar, nos moldes da sociedade patriarcal. Dedicando-se estritamente ao marido e à filha, seus dias são 
insistentemente iguais, no ambiente interno, representado pela casa, local onde vive atrás de uma janela observando unicamente a passagem do tempo. Não por acaso é que ser "mulher casada” remete a aspectos negativos; prova disso são os vocábulos e os termos que compõem o campo semântico referente ao matrimônio:

\begin{abstract}
Agora a chuva parou. Só está frio e muito bom. Não voltarei para casa. Ah, sim, é infinitamente consolador. Ele ficará surpreso? Sim, doze anos pesam como quilos de chumbo. Os dias se derretem, fundem-se e formam um só bloco, uma grande âncora. E a pessoa está perdida. Seu olhar adquire um jeito de poço fundo. Água escura e silenciosa. Seus gestos tornam-se brancos e ela só tem um medo na vida: que alguma coisa venha transformá-la. Vive atrás de uma janela, olhando pelos vidros a estação das chuvas cobrir o a do sol, depois tornar o verão e ainda as chuvas de novo. [...].

Ela ri. Agora pode rir...Eu comia caindo, dormia caindo, vivia caindo. Vou procurar um lugar onde pôr os pés. (LISPECTOR, 2016a, p. 90, grifos nossos).
\end{abstract}

Além da monotonia diária que coloca Elvira atrás de uma janela para observar a passagem do tempo, rotina que a personagem vivencia há 12 anos (“doze séculos”), também é possível constatar que o casamento está relacionado a algo que "pesa”; associação estabelecida com "quilos de chumbo" e "grande âncora”. O vocábulo âncora se refere a uma peça de ferro composta por duas ou mais pontas presa a uma corrente que é lançada ao mar com o objetivo de fixar e impedir a movimentação de embarcações (DICIO, 2014). Transpondo esse conceito para a narrativa, pode-se dizer que o casamento atua como "âncora”, capaz de acorrentá-la e afundá-la, impedindo-a de se emancipar. Ao explorarem a simbologia dos 12 anos de casamento, El Fahl e Rocha (2017, p. 22) ressaltam que o seu significado é apresentado às avessas por Clarice: "Ao contrário da maciez da seda, símbolo dos 12 anos de casamento, esse tinha a densidade do chumbo. Este peso se assemelha para ela a uma grande âncora a puxá-la para baixo, tornando-a inerte e cada vez mais fixada ao seu papel doméstico [...]”. O mesmo vale para a expressão “quilos de chumbo", que reforça o fardo desses 12 anos de casamento. No sentido conotativo, refere-se ao acúmulo de experiências, vivências e atribulações que, consequentemente, tornam-se algo “pesado” para o indivíduo suportar e carregar.

Ainda no que tange aos aspectos negativos relacionados à vida de mulher casada, no último parágrafo do excerto anterior - "Ela ri. Agora pode rir...Eu comia caindo, dormia caindo, vivia caindo. Vou procurar um lugar onde pôr os pés” (LISPECTOR, 2016a, p. 90) -, pode-se verificar que o narrador se omite e cede espaço para a reprodução do fluxo de pensamentos da própria personagem. Esse fragmento só pode ser compreendido se associado ao relato do narrador que, páginas antes, apresenta um período da infância da personagem, em que ela, na escola, inventara um homem com um sério problema: “Com ele a força da gravidade não pegava... Então ele caía para fora da terra, e ficava caindo sempre, porque ela não sabia lhe dar um destino” (LISPECTOR, 2016a, p. 89). Então, quando Elvira expressa que comia, dormia, vivia “caindo”, utilizando tempo verbal que denota duração dos fatos no tempo, remonta à ideia de algo que se repetia continuamente e do qual quer se libertar; daí a busca por um lugar onde colocar os pés. Mais uma vez, o casamento aparece carregado de um sentido pejorativo; aqui de estagnação e imobilidade. Justifica-se, portanto, o riso de Elvira, que traduz a satisfação de estar livre para caminhar, viver, buscar sua emancipação e seu próprio destino como “mulher”. 
A partir, então, da seleção vocabular e do campo semântico empregado, pode-se afirmar que Clarice, sem ser uma feminista panfletária que escancara ideais feministas, põe à mostra, sob o viés da crítica social, os valores da sociedade patriarcal (XAVIER, 1999), e o casamento que, no conto, é sinônimo de enclausuramento, fixidez e opressão. Nesse contexto, a figura do marido não apenas concorre para a inibição da liberdade de Elvira, tolhendo os seus pensamentos e desejos, mas também representa, ainda que de forma sutil, a superioridade masculina, que se ratifica pelos papéis desempenhados e espaços sociais ocupados por cada um:

Porque seu marido tinha uma propriedade singular: bastava sua presença para que os menores movimentos de seu pensamento ficassem tolhidos. A princípio, isso lhe trouxera certa tranquilidade, pois costumava cansar-se pensando em coisas inúteis, apesar de divertidas. (LISPECTOR, 2016a, p. 89-90).

Segundo o Dicionário Houaiss de Língua Portuguesa, o verbo tolher significa “[...] causar embaraço ou impedimento; estorvar; pôr obstáculo a; opor-se; obstar; impor proibição; proibir; vedar; não deixar manifestar-se; coibir; embargar; impedir; privar de” (HOUAISS; VILLAR, 2001, p. 2730). Sinônimos que, apesar de não empregar violência física, dialoga com o conceito de violência simbólica apresentada por Bourdieu:

Também sempre vi na dominação masculina, e no modo como é imposta e vivenciada, o exemplo por excelência desta submissão paradoxal, resultante daquilo que eu chamo de violência simbólica violência suave, insensível, invisível a suas próprias vítimas, que se exerce essencialmente pelas vias puramente simbólicas da comunicação e do conhecimento [...]. (BOURDIEU, 2012, p. 7-8).

No entanto, além de impedir/proibir/coibir os pensamentos da protagonista, o marido também exerce a sua autoridade controlando os seus desejos; representação do "bom senso":

Seus gestos tornam-se brancos e ela só tem um medo na vida: que alguma coisa venha transformá-la. [...]. Os desejos são fantasmas que se diluem mal se acende a lâmpada do bom senso. Por que é que os maridos são o bom senso? O seu é particularmente sólido, bom e nunca erra. Das pessoas que só usam uma marca de lápis e dizem de cor o que está escrito na sola dos sapatos. Você pode perguntar-lhes sem receio qual o horário dos trens, o jornal de maior circulação e mesmo em que região do globo os macacos se reproduzem com maior rapidez. (LISPECTOR, 2016a, p. 90, grifos nossos).

Novamente, nesse trecho, o campo semântico utilizado carrega muitos sentidos que encaminham para a questões relacionados ao casamento e seus desdobramentos na vida da mulher. "Gestos brancos”, por exemplo, convidam o leitor a pensar no apagamento das atitudes, ações e anseios de Elvira; neutralizados pelo "bom senso" do marido, cuja expressão alude a discernimento, juízo, a uma forma sensata e equilibrada de decidir e julgar; razoabilidade, prudência; modo de agir que não é afetada pelas paixões, e que se pauta na razão, no equilíbrio, de acordo com a moral e os padrões (DICIO, 2009). Evidentemente que ter "bom senso" é uma qualidade que, na justa medida, é adequado e até desejável. No entanto, a sensatez, o equilíbrio e a capacidade de discernir o que é “certo” e “errado” do marido concorrem para que 
Elvira se "apague” como indivíduo, haja vista que seus gestos se tornaram "brancos” e seus desejos, "fantasmas". O marido é, ainda, descrito como alguém sólido, bom, que nunca erra e cujo conhecimento não tem limites; o que insinua a sua personalidade de indivíduo "infalível" e “perfeito”. Mais uma razão para a progressiva invisibilidade e objetificação da protagonista.

Já em um cenário pós fuga, Elvira caminha livre e solitária pelas ruas do Rio de Janeiro, e suas ideias e pensamentos mostram-se confusos e contraditórios, pois, apesar de desejar a liberdade, se questiona sobre voltar ou não para o seu lar: "Pensava sempre: 'Mas que é que vai acontecer agora?’ Se ficasse andando. Não era solução. Voltar para casa? Não. [...]. Tonta como estava, fechou os olhos e imaginou um grande turbilhão saindo do 'Lar Elvira'” (LISPECTOR, 2016a, p. 88). Diferentemente do campo semântico que evoca o casamento, os que se referem à fuga e ao espaço externo denotam alegria, alívio pois “[...] três horas de liberdade restituíam-na quase inteira a si mesma [...]” (LISPECTOR, 2016a, p. 88-89). Não obstante a hesitação em prosseguir, o sentimento de estar desprendida de seu papel social de esposa motiva a protagonista a manter o seu plano.

Com a fuga, Elvira rompe com um padrão de comportamento esperado para uma mulher da primeira metade do século XX, que, segundo Dalcastagnè (2005), geralmente são donas-de-casa, artistas (em geral, atrizes), estudantes, domésticas, professoras, prostitutas, e que estão destinadas a viverem apenas no espaço interno da casa: “A personagem que caminha pela cidade é, via de regra, o homem. Às mulheres, cabe a esfera doméstica, o mundo que a ficção lhes destina” (DALCASTAGNÈ, 2005, p. 43).

Não obstante as dúvidas e os receios, e de estar em um espaço pertencente (quase) exclusivamente ao masculino, a personagem segue seu caminho rumo à sua independência: "Ela tomara o ônibus na Tijuca e saltara na Glória. Já andara para além do Morro da Viúva” (LISPECTOR, 2016a, p. 89). No bairro da Glória, depara-se com o mar; elemento da natureza que, mais uma vez, carrega uma forte carga metafórica, pois desnuda os impasses vivenciados pela protagonista. $\mathrm{O}$ mar e outros elementos que remetem à presença da água, quando presentes nas obras de Clarice, incidem na construção da personagem, refletindo sua interioridade; em “A fuga” não é diferente:

O mar revolvia-se forte e, quando as ondas quebravam junto às pedras, a espuma salgada salpicava-a toda. Ficou um momento pensando se aquele trecho seria fundo, porque tornava-se impossível adivinhar: as águas escuras, sombrias, tanto poderiam estar a centímetros da areia quanto esconder o infinito. Resolveu tentar de novo aquela brincadeira, agora que estava livre. Bastava olhar demoradamente para dentro d'água e pensar que aquele mundo não tinha fim. Era como se estivesse se afogando e nunca encontrasse o fundo do mar com os pés. Uma angústia pesada. (LISPECTOR, 2016a, p. 89).

Os sentimentos desencadeados pelo mar e seus mistérios aludem ao jogo de oposições que atravessa o conto. O mar não apenas contrasta com a simbologia da âncora que aprisiona e fixa a protagonista em um único lugar, mas sua imensidão e profundidade, sem limite, também traduzem a ideia de libertação adquirida com a fuga, permitindo-lhe infinitas possibilidades de explorar o mundo, sem as amarras do casamento: 
Vale notar que a imagem do casamento como âncora a mantê-la presa no mar, sem poder experimentar de sua imensidão, contrasta com outras imagens que Elvira gera em sua reflexão, como quando contempla a água escura, imaginando o fundo do mar, tão imenso; a imagem do navio que viaja livre pelos oceanos, ou do homem imaginado na infância, a quem a gravidade não podia conter e que se movia pelo globo com toda liberdade e fluidez. (EL FAHL; ROCHA, 2017, p. 22).

Considerando a análise desenvolvida até aqui, importa destacar que o conto fratura a linearidade narrativa, pois os acontecimentos não são narrados em ordem cronológica. Tanto a epifania quanto os momentos que o leitor tem acesso às problemáticas vivenciadas pela personagem são apresentados sob a perspectiva subjetiva do tempo, que nada tem a ver com o tempo do relógio. Não por acaso, os níveis temporais passam a se confundir sem demarcação nítida entre presente, passado e futuro, isso porque a “[...] nossa consciência não passa apenas por uma sucessão de momentos neutros, como o ponteiro de um relógio, mas cada momento contém todos os momentos anteriores” (ROSENFELD, 1985, p. 82). Ao submergir na corrente psíquica de Elvira, o narrador traz à tona a sua consciência, cuja totalidade engloba, como atualidade, presente e passado, e o futuro, como um horizonte de possibilidades e expectativas:

Agora está com fome. Há doze anos não sente fome. Entrará num restaurante. O pão é fresco, a sopa é quente. Pedirá café, um café cheiroso e forte. Ah, como tudo é lindo e tem encanto. O quarto do hotel tem um ar estrangeiro, o travesseiro é macio, perfumada a roupa limpa. E quando o escuro dominar o aposento uma lua enorme surgirá, depois dessa chuva, uma lua fresca e serena. E ela dormirá coberta de luar.

Amanhecerá. Terá a manhã livre para comprar o necessário para a viagem, porque o navio parte às duas horas da tarde. O mar está quieto, quase sem ondas. O céu de um azul violento, gritante. O navio se afasta rapidamente... E em breve o silêncio. As águas cantam no casco, com suavidade, cadência... Em torno, as gaivotas esvoaçam, brancas espumas fugidas do mar. Sim, tudo isso! (LISPECTOR, 2016a, p. 91-92).

Desarticulação temporal que também se traduz na perda de fronteira espacial. Constata-se nesse excerto que os espaços - restaurante, quarto de hotel e navio - figuram de forma simultânea na mente de Elvira; todos relacionados ao cenário pós fuga e aos planos que Elvira almeja realizar. Não obstante esses espaços e o tempo verbal se localizarem predominantemente no futuro, apresenta-se, entretanto, no tempo presente. Exemplo disso é o trecho em que a personagem planeja entrar no restaurante e, logo em seguida, já o descreve como se já estivesse no local. Essa desarticulação temporal/espacial se deve à tentativa do narrador heterodiegético que, embora relate uma história à qual é estranho, uma vez que não integra como personagem o universo diegético em questão, busca reproduzir o fluxo de consciência da protagonista. Por isso, não raro o narrador desaparece, substituído pela presença direta do fluxo psíquico de Elvira, como em trecho já anteriormente transcrito: “Agora a chuva parou. Só está frio e muito bom. Não voltarei para casa. Ah, sim, isso é infinitamente consolador. Ele ficará surpreso? Sim, doze anos pesam como quilos de chumbo" (LISPECTOR, 2016a, p. 90). Ou, ainda: “Oh, tudo isso é mentira. [...]. Não posso ter raiva de mim, porque estou cansada. E mesmo tudo está acontecendo, eu nada estou provocando” (LISPECTOR, 2016a, p. 92). Desse modo, ainda que 
o narrador atue como mediador dos eventos narrativos, apresentando a personagem no distanciamento gramatical do pronome "ela” e da voz do pretérito, em alguns trechos a consciência de Elvira manifesta-se na sua atualidade imediata, em pleno ato presente, como um Eu que ocupa o conto. Aspecto que leva ao desaparecimento da coerência e da linearidade da estrutura em que o narrador clássico imprimia à sequência dos acontecimentos, com seu encadeamento lógico de motivos e situações, com seu início, meio e fim.

Termômetro disso é que o conto se inicia em um cenário pós fuga, em que a protagonista está em um ambiente externo, após ter abandonado o lar: "Começou a ficar escuro e ela teve medo. A chuva caía sem tréguas e as calçadas brilhavam úmidas à luz das lâmpadas. [...]. Quis sentar-se num banco de jardim, porque na verdade não sentia a chuva e não se importava com o frio” (LISPECTOR, 2016a, p. 88). Ao lançar o leitor nos acontecimentos em andamento, os quais são exibidos sob ponto de vista da protagonista, por meio da focalização interna, o narrador, diferentemente da narrativa tradicional que utiliza recursos narrativos como a analepse para apresentar ao leitor fatos que antecedem o presente da enunciação, em “A fuga” o enredo se configura por meio do monólogo interior e do fluxo de pensamentos da personagem, abolindo, assim, o tempo cronológico:

Estava cansada. Pensava sempre: “Mas que é que vai acontecer agora?” Se ficasse andando. Não era solução. Voltar para casa? Não. Receava que alguma força a empurrasse para o ponto de partida. Tonta como estava, fechou os olhos e imaginou um grande turbilhão saindo do "Lar Elvira”. Assustou-se. Esperou um momento em que ninguém passava para dizer com toda a força: "Você não voltará." Apaziguou-se. (LISPECTOR, 2016a, p. 88).

Nesse trecho, presente nos parágrafos iniciais do conto, o leitor consegue discernir que a protagonista fugiu de casa e reluta retornar ao lar, devido às problemáticas ligadas ao casamento; situação narrativa que antecede a fuga propriamente dita e revelada pelo monólogo interior. No excerto, ainda que a utilização das aspas acene para diferenciar a voz do narrador da personagem, a impressão que fica é que apenas a consciência de Elvira está sendo exposta, ocupando o primeiro plano da narração. Desse modo, a desarticulação temporal e espacial, consequência do desaparecimento (mesmo que temporário) do narrador, abre espaço para a manifestação do tempo vivencial da protagonista, que é exposto pelo monólogo interior, capaz de reproduzir seu fluxo de consciência e tornar o leitor um participante que mergulha na própria experiência da personagem (ROSENFELD, 1985).

Encaminhando para o desfecho da narrativa, não obstante o desejo de tornar-se livre, Elvira decide voltar para a casa, o que parece evidenciar que a mulher está condenada à posição e aos papéis sociais que desempenha, caminhando para um beco sem saída. A viagem de navio, senha para sua alforria, se mostra distante:

Mas ela não tem suficiente dinheiro para viajar. As passagens são tão caras. E toda aquela chuva que apanhou, deixou-lhe um frio agudo por dentro. Bem que pode ir a um hotel. Isso é verdade. Mas os hotéis do Rio não são próprios para uma senhora desacompanhada, salvo os de primeira classe. E nestes pode talvez encontrar algum conhecido do marido, o que certamente lhe prejudicará os negócios. (LISPECTOR, 2016a, p. 92) 
As barreiras para prosseguir são diversas, mas todas relacionadas ao funcionamento da ordem social, que divide os papéis sociais, espaços a serem frequentados e funções atribuídas a cada indivíduo pelo gênero; o que tende a ratificar a dominação masculina, que coloca a mulher em uma posição de submissão e dependência (BOURDIEU, 2012). É, então, nesse contexto, que a protagonista pondera e resolve voltar ao "Lar Elvira":

Oh, tudo isso é mentira. Qual a verdade? Doze anos pesam como quilos de chumbo e os dias se fecham em torno do corpo da gente e apertam cada vez mais. Volto para casa. Não posso ter raiva de mim, porque estou cansada. E mesmo tudo está acontecendo, eu nada estou provocando. São doze anos. (LISPECTOR, 2016a, p. 92).

Tragado pelo fluxo psíquico da personagem, o leitor identifica, contudo, que os impedimentos anteriormente apresentados - dependência financeira e valores machistas presentes na sociedade - apesar de vigorarem no constructo social, não exprimem a sua "real” vulnerabilidade. O casamento, somente ele que "pesa como quilos de chumbos” e que "aperta cada vez mais”, torna a emancipação e a busca por uma nova realidade de ser e de viver um desejo distante, como "o navio que se afasta cada vez mais":

Entra em casa. É tarde e seu marido está lendo na cama. Diz-lhe que Rosinha esteve doente. Não recebeu seu recado avisando que só voltaria de noite? Não, diz ele.

Toma um copo de leite quente porque não tem fome. Veste um pijama de flanela azul, de pintinhas brancas, muito macio mesmo. Pede ao marido que apague a luz. Ele beija-a no rosto e diz que o acorde às sete horas em ponto. Ela promete, ele torce o comutador [...].

Fica de olhos abertos durante algum tempo. Depois enxuga as lágrimas com o lençol, fecha os olhos e ajeita-se na cama. Sente o luar cobri-la vagarosamente. Dentro do silêncio da noite, o navio se afasta cada vez mais. (LISPECTOR, 2016a, p. 92).

Considerando o desfecho, pode-se afirmar que “A fuga” em muito se assemelha a outro conto da autora, “Amor”, publicado em Laços de família, em 1960. Assim como Elvira, Ana desempenha papéis sociais de esposa, mãe e dona do lar e, como ela, também é provocada a rever a sua vida quando vê um cego mascando chicletes (LISPECTOR, 2016b). O retorno ao lar não significa, no entanto, que o processo de autodescoberta e independência tenha ficado para trás. Ao contrário, está latente e tende a se impor, já que os impasses e as hesitações de Elvira e Ana são figuradas, não raro, pela perspectiva das próprias protagonistas, que desnudam, de um lado, a face de um casamento infeliz, que se desdobra no aprisionamento e na submissão feminina e, de outro, em uma crítica social aos valores patriarcais.

\section{CONSIDERAÇÕES FINAIS}

Na recepção crítica do primeiro romance publicado por Clarice Lispector, salta aos olhos a ideia de uma escritora notadamente "diferente” da maioria que publicava àquela altura da década de 1940. O fato de Clarice apresentar um outro modelo narrativo e estético trouxe desatino à crítica literária brasileira da época, que não sabia “ler” seus escritos, pois estava dentro 
de um panorama literário impregnado pelos mesmos temas e preocupações. Exemplo disso é Lins (1944), que classificou Perto do coração selvagem como sentimental, porque carregado de lirismo; leitura que se perpetuou não apenas para a produção literária de Clarice, mas para a literatura de autoria feminina.

Nesse contexto também foi publicado o conto “A fuga”, que busca retratar a subjetividade e os dilemas íntimos experimentados por Elvira, figurados pelo monólogo interior, pela focalização interna e, não raro, pelo movimento miúdo das emoções e dos pensamentos da própria protagonista. Esses recursos narrativos empregados pela autora, mais do que revelar os conflitos individuais de Elvira, têm um alcance coletivo, na medida em que evidencia os sentimentos e o universo psíquico da realidade da mulher, cuja existência está atrelada à tradição patriarcal. Não por acaso é que Elvira e diversas outras personagens clariceanas estão sempre em uma busca incansável de si mesmas, na procura de um “eu” interior e de sua própria identidade, almejando a emancipação e a liberdade; desejo coletivo expresso pela voz de Joana, em Perto do coração selvagem: "Prisão, liberdade. São essas as palavras que me ocorrem. No entanto não são as verdadeiras, únicas e insubstituíveis, sinto-o. Liberdade é pouco. O que desejo ainda não tem nome” (LISPECTOR, 1998b, p. 70).

Diante do exposto, “A fuga” é capaz de mimetizar papéis sociais e posições ocupados pelas mulheres dentro do funcionamento da ordem social, que tende a ratificar a dominação masculina, inscrevendo-as em uma posição de subalternidade (BOURDIEU, 2012). Assim, Elvira é a representação fictícia de mulheres aprisionadas à sua condição social e de gênero, mas que buscam se desvencilhar do "aprisionamento", representado no conto pelo casamento. Como observado no desfecho, isso não é uma tarefa fácil, pois a personagem não consegue libertar-se do matrimônio, que a imobiliza e a leva ao apagamento paulatino de si mesma; aspecto que não deixa de suscitar no leitor a crítica social promovida pelo conto aos valores tradicionais e aos padrões dominantes.

\section{REFERENCIAS}

BOSI, A. História concisa da literatura brasileira. 50. ed. São Paulo: Cultrix, 2015.

BOURDIEU, P. A dominação masculina. Tradução de Maria Helena Kühner. 11. ed. Rio de Janeiro: Bertrand Brasil, 2012.

BRASIL, A. Clarice Lispector: ensaio. Rio de Janeiro: Organização Simões, 1969.

CANDIDO, A. No raiar de Clarice Lispector. In: CANDIDO, A. (org.). Vários escritos. São Paulo: Duas Cidades, 1970. p. 125-131.

CANDIDO, A. Literatura e subdesenvolvimento. In: CANDIDO, A. (org.). Educação pela noite e outros ensaios. São Paulo: Ática, 1987a. p. 140-162.

CANDIDO, A. A nova narrativa. In: CANDIDO, A. (org.). Educação pela noite e outros ensaios. São Paulo: Ática, 1987b. p. 199-215.

DALCASTAGNÈ, R. A personagem do romance brasileiro contemporâneo: 1990-2004. Estudos de Literatura Brasileira Contemporânea, Brasília, n. 26, p. 13-71, jul./dez. 2005. 
DICIO. Dicionário Online de Português. Significado de âncora. 2014. Disponível em: https:// www.dicio.com.br/ancora/. Acesso em: 15 jul. 2020.

DICIO. Dicionário Online de Português. Significado de bom senso. 2009. Disponível em: https://www.dicio.com.br/bom-senso/. Acesso em: 15 jul. 2020.

EL FAHL, A. de O. F.; ROCHA, F. A. de B. A lâmpada do desejo: uma leitura do conto A fuga de Clarice Lispector. Revista A Cor das Letras, Feira de Santana, v. 18, n. 1, p. 19-27, jan./ abr. 2017. DOI: http://dx.doi.org/10.13102/cl.v18i1.1683

HOUAISS, A.; VILLAR, M. S. Dicionário Houaiss da Língua Portuguesa. Rio de Janeiro: Objetiva, 2001.

LINS, A. A experiência incompleta: Clarisse Lispector. Jornal de crítica, Rio de Janeiro, fev. 1944.

LISPECTOR, C. Água viva. Rio de Janeiro: Rocco, 1998a.

LISPECTOR, C. Perto do coração selvagem. Rio de Janeiro: Rocco, 1998b.

LISPECTOR, C. Uma aprendizagem ou o livro dos prazeres. Rio de Janeiro: Rocco, 1998c.

LISPECTOR, C. A bela e a fera. Rio de Janeiro: Rocco, 1999a.

LISPECTOR, C. A descoberta do mundo. Rio de Janeiro: Rocco, 1999b.

LISPECTOR, C. A fuga. In: LISPECTOR, C. Todos os contos. Prefácio e organização de Benjamin Moser. Rio de Janeiro: Rocco, 2016a. p. 88-92.

LISPECTOR, C. Amor. In: LISPECTOR, C. Todos os contos. Prefácio e organização de Benjamin Moser. Rio de Janeiro: Rocco, 2016b. p. 145-155.

LISPECTOR, C. Todos os contos. Prefácio e organização de Benjamin Moser. Rio de Janeiro: Rocco, 2016c.

NOGUEIRA, R. M. A evolução da sociedade patriarcal e sua influência sobre a identidade feminina e a violência de gênero. Revista Jus Navigandi, Teresina, maio 2016. Disponível em: https://jus.com.br/artigos/48718. Acesso em: 16 set. 2020.

NUNES, B. O drama da linguagem: uma leitura de Clarice Lispector. São Paulo: Ática, 1989.

ROSENBAUM, Y. Clarice Lispector. São Paulo: Publifolha, 2002.

ROSENFELD, A. Reflexões sobre o Romance Moderno. In: ROSENFELD, A. (org.). Texto/ Contexto I. São Paulo: Editora Perspectiva, 1985. p. 75-97.

SANTIAGO, S. A aula inaugural de Clarice. In: MIRANDA, W. M. (org.). Narrativas da modernidade. Belo Horizonte: Autêntica, 1999. p. 13-30.

SÜSSEKIND, F. Tal Brasil, qual romance? Rio de Janeiro: Achiamé, 1984. 
XAVIER, E. Narrativa de autoria feminina na literatura brasileira: as marcas da trajetória. Revista Mulheres e Literatura, Rio de Janeiro, v. 3. p. 1-4, 1999. Disponível em: http://litcult. net/category/mulheresrev/revista-mulheres-e-literatura-vol-3-1999. Acesso em: 5 fev. 2020.

ZOLIN, L. O. Espaços (des)interditados: o lugar da mulher na narrativa de autoria feminina paranaense contemporânea. In: DALCASTAGNÈ, R.; LEAL, V. M. V. (org.). Espaço e gênero na literatura brasileira contemporânea. Porto Alegre: Zouk, 2015. p. 197-237. 